\title{
Adoption and Impact of improved Groundnut Seed Varieties Among Groundnut Farmers: Case of Albasu Local Government Area of Kano State, Nigeria
}

\section{H. Shuaibu}

Department of Agricultural Extension and Rural Development, Faculty of Agriculture, Ahmadu Bello University, Zaria [E-mail: shuaibuhajara2839@gmail.com; hskugu@yahoo.com; D: +2347031187744]

\begin{abstract}
This study assessed the level of adoption and impact of improved groundnut seed varieties among groundnut farmers in Albasu Local Government Area of Kano State, Nigeria. A multistage simple random sampling was used to select the respondents across the local government area, wards and villages to give 120 respondents. Data were collected with structured questionnaire and analyzed with simple descriptive statistics, Z-test and logit regression analysis. Results showed that for both adopters and non-adopters, majority had mean ages of 44 and 41 years, mean household sizes of 7 and 6 people, had no formal education (21 and 46\%), mean farm sizes of 2.2 and 1.4 ha, mean farming experience of 17 and16 years, no extension contact (21 and 64\%), and low membership of cooperative (33 and 8\%). There was low adoption $(27 \%)$ of the improved seed varieties which impacted positively on the adopters (Z-value $=3.727$, $p<0.01)$. Age $(\beta=0.035, p<0.01)$, educational level $(\beta=0.667, p<0.01)$, farming experience $(\beta=1.386, p<0.01)$ and membership of cooperative $(\beta=0.718, p<0.01)$ significantly influence probability of adoption of improved groundnut seeds by the farmers. It was therefore recommended that research institutes in charge of developing the seeds and ADPs should improve on their efforts to promote the technology to farmers for more adoption.
\end{abstract}

Keywords: Adoption, groundnut seeds, groundnut farmers, Kano State.

\section{INTRODUCTION}

Agriculture remains a key component of the Nigerian economy and dominates the labour market by employing about half $(48.19 \%)$ of total workers (National Bureau of Statistics, NBS, 2018) and by the first quarter of 2016 contributes $19.17 \%$ to the country's Gross Domestic Product (NBS, 2016). It constitutes the single largest contributor to the wellbeing of the rural poor, sustaining $90 \%$ of the rural labor force. In Nigeria, groundnut (Arachis hypogaea L.) is a major crop produced in almost all northern States including Kano, Niger, Jigawa, Sokoto, Katsina, Zamfara, Kaduna, Adamawa, Bauchi, Yobe, Plateau, Kebbi, Borno, Taraba, Gombe and Nasarawa States (NAERLS, 2011). The crop contributed immensely to the development of Nigerian economy between 1956-1967 accounting for about $70 \%$ of total Nigeria export earnings making it the country's most valuable single export crop ahead of other cash crops (Harkness, 1976). Groundnut also provides multiple benefits to smallholder farmers growing the crop. It serves as an inexpensive source of protein to families who cannot afford the more expensive animalbased diets (Rachier, 2005). For households who can afford to produce a surplus for markets, it provides scarce cash income that can be used for investing in health, children's education, and other necessities. This makes groundnut an important food security crop in both rural and urban areas of Uganda (Obuo et al., 2004). As a legume crop, groundnut also provides additional benefit for enhancing soil fertility through fixation of atmospheric nitrogen, especially important given the inflated cost of chemical fertilizers. This contributes to increased land and labor productivity for smallholder producers (Coelli and Fleming 2004). In many communities where the crop is grown, its leaves and haulms make nutritious animal feeds, while the groundnut meal - a byproduct of oil extraction - serves as another important protein supplement for livestock. 
Despite of the numerous benefits and roles groundnut play at individual to national level in Nigeria, pod yield from farmers' field have remain low averaging $1082 \mathrm{~kg} \mathrm{ha}^{-1}$ compared to $3000 \mathrm{~kg}$ $\mathrm{ha}^{-1}$ and $3500 \mathrm{~kg} \mathrm{ha}^{-1}$ potential yield and those from developed countries respectively (Ndjeunga et al., 2010). The large gap has been attributed to several factors such as poor soil fertility, continued used of poor yielding indigenous varieties, inappropriate crop management practices, pests and diseases (Ahmed et al., 2010 in Zekeri and Tijjani, 2013). In view of this, Research Institutes (notably ICRISAT and IAR) have developed several improved varieties over the years which are disease resistant (especially rosette), drought tolerant, early maturing, high oil content and high-yielding cultivars. These varieties are SAMNUT 1-20, released between 1988 to 1992 , SAMNUT 21-23 released in 2000, SAMNUT 24 released in 2011 and by 2015 SAMNUT 25 and 26 have been released (National Centre for Genetic Resources and Biotechnology, NACGRAB, 2011). Most of these have been promoted widely for adoption.

In Nigeria, although these improved varieties have been available for decades, complete adoption has not, so far, been achieved (Ndjeunga et al., 2013). Transformation of traditional farming system for increased food production calls for adoption of improved technology. Innovations in agricultural development are of little value until they can be put to use for the economic and social well-being of the people involved. The adoption of highyielding-varieties of crops by farmers in developing countries has been viewed as the solution to lower incomes in agriculture over the years (Besley and Case, 1993). Technology adoption has a direct effect on the farmer's income, usually resulting from higher yields, higher prices, or both. This observation has, therefore, spawned numerous studies about agricultural technology adoption related issues in recent years (Mendola, 2007; Becerril and Abdulai, 2009). One of the major challenges facing agricultural policy makers is the need for the investigation of those factors which contribute to the adoption of improved farm technology (Odoemenem and Obinne, 2010). This study therefore examined the factors influencing farmers' adoption of improved groundnut seed variety in the study area. Specifically, the study identified the socio-economic characteristics of the respondents; investigated level of awareness and adoption of the improved seed varieties; and determined the factors influencing adoption of the improved seed varieties.

\section{METHODOLOGY}

The study was carried out in Albasu Local Government Area, of Kano State and lies between latitude $11040261 \mathrm{~N}$ and longitude 9o $0828 \mathrm{E}$ of the equator. Dry and wet seasons are the two distinct seasons in the area with the wet season beginning between May and June and lasts for 5 month and dry season begins in November and ends around late May. Mean annual rainfall varies between $750 \mathrm{~mm}$ and $1000 \mathrm{~mm}$ and the mean maximum ambient temperature varies from $25-35^{\circ} \mathrm{C}$ depending on the season. The average relative humidity during the wet season is about $70 \%$ and during hammatan period is about $20 \%$. Albasu Local Government has an estimated population of about 231, 141 (projection as of 2014) with an area of $398, \mathrm{Km}^{2}$. Major crops grown are sorghum, groundnut, millet and vegetables. The area is predominantly rural and dominated by Hausa/Fulani ethnic group.

Sampling procedure adopted was multi-stage random sampling technique. First six wards (Tsangaya, Albasu, Daho, Gagarame, Panda and Faragai) were randomly selected from eleven wards in the area. Then in each ward, two villages were randomly selected making a total of 12 villages, and finally ten groundnut were randomly selected from each village to give sample size of 120 respondents. Primary data were collected with the aid of structured questionnaire. The questionnaire was administered to the respondent in the study area with the help of enumerators. Data collected from 
the respondents includes information on socioeconomic characteristics of the farmers, yield obtained from crop production and type of seed used.

\section{Statistical Analysis}

Data were analysed with simple descriptive statistics, Z-test and logit regression analysis.

\section{The Z-statistic}

The yield of adopters and non-adopters of improved groundnut seed was compared to see its impact using the Z-test statistics. The model is expressed as follows:

$$
Z=\frac{X_{1}-X_{2}}{\sqrt{\frac{\delta_{1}^{2}+\delta_{2}^{2}}{n_{1}+n_{2}}}}
$$

Where:

$\mathrm{Z}$ = calculated Z-value

$X_{1}=$ mean value of adopters yield.

$X_{2}=$ mean value of non-adopters yield.

$\delta_{1}^{2}=$ standard deviation of adopters yield.

$\delta_{2}^{2}=$ standard deviation of non-adopters yield.

$n_{1}=$ sample size of adopters.

$n_{2}=$ sample size of non-adopters.

Logistics Regression Analysis

To determine the socio-economic and institutional factors influencing the adoption of improved groundnut varieties, the factors were regressed against the logistic model as expressed below:

$$
P i=\frac{1}{1+e-Z i}
$$

$P i$ ranges between zero and one it is non-linearly related to $Z i$. $Z i$ is the stimulus index which ranges from minus infinity to plus infinity. To obtain the value of $Z i$, the likelihood of observing the sample were formed by introducing a dichotomous response variable. The explicit logit model is expressed as:

$$
Y=\beta_{0}+\beta_{1} X_{1}+\beta_{2} X_{2}+\ldots+\beta_{8} X_{8}+u
$$

Where:

$Y=$ adoption status $(1=$ food secured, $0=$ food insecured).

$X_{1}=$ age (years)

$X_{2}=$ household size (number)

$X_{3}=$ years of formal education

$X_{4}=$ farm size

$X_{5}=$ extension visit per year (number)

$X_{6}=$ farming experience (years)

$\mathrm{X}_{7}=$ land tenure

$\mathrm{X}_{8}=$ years of membership in cooperative associations

$\beta_{0}=$ constant

$\beta_{1}-\beta_{8}=$ coefficients or standardized partial

regression coefficients

$u=$ error term

\section{RESULTS AND DISCUSSION Rate of Adoption of Improved Groundnut Seed Variety}

The distribution of respondent by rate of adoption is presented in Figure 1. The result shows that only about $27 \%$ of the respondents adopted and used improved groundnut seed in the study area while $73 \%$ continue to use local varieties available to them. This implies that there is low adoption rate of the varieties among the sampled farmers. This is in spite of the presence of ICRISAT and IAR Institutes in Kano State who have been working for almost three decades to improve in the qualities of groundnut. The possible reason for the low adoption could be attributed to low awareness and/or ineffective dissemination of the technology to farmers. High adoption of any technology is consistent with greater awareness of that technology. Salisu et al. (2007) also noted that farmers' adoption of any improved technology is positively correlated with awareness. 


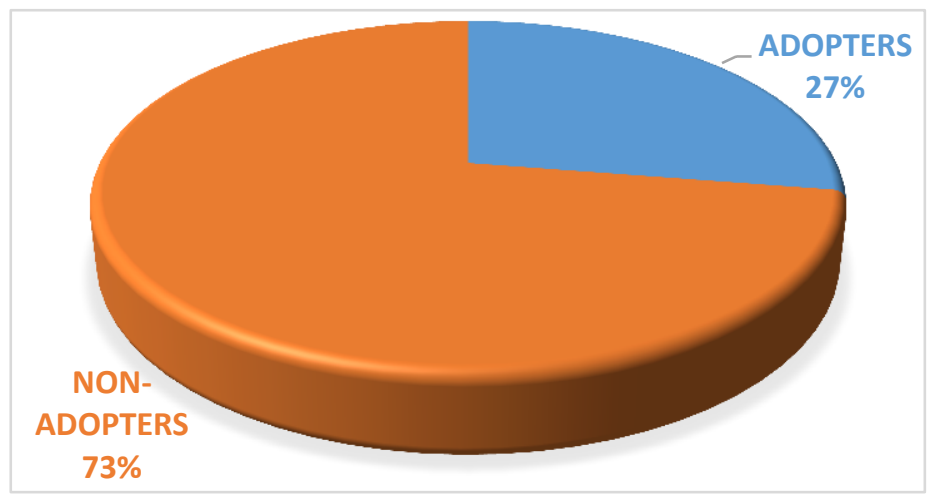

Figure I: Level of Adoption of Improved Groundnut Seed among Farmers

\section{Socio-Economic Characteristics of the Respondents}

Table 1 represents the socioeconomic characteristics of the respondents studied. These characteristics include age, household size, educational level, farm size, extension contact, farming experience and membership of cooperative. The Table shows that the average ages for adopters and non-adopters were 44 and 41 years respectively, while the average age for the combined groups was 41.8 years. This indicates that the farmers are young and are supposed to be physically able and mentally more open to learn new technologies than older farmers. The result mirrored the findings of Mugisha et al. (2004) and Idoko and Sabo (2014). The result further revealed that adopters had larger household size as about $45 \%$ of them were in the range of 5-10 members per household while more than half of non-adopters had less five people per household which translates to average household size of 7 and 6 for adopters and non-adopters respectively. The size is by far less than what Ibrahim et al. (2012) found in sub-Saharan Africa but is still a relatively large size. This ensures readily available household labour with reduced labour cost required for groundnut production (Ndanitsa and Umar, 2007).

For educational qualification, it could be seen that a high proportion $(46.0 \%)$ of the non-adopters had no formal schooling as compared to adopters
(21\%) (Table 1). As this study was undertaken in the rural parts of the country, it is not surprising as confirmed by Ahmed et al. (2016) where he revealed that about $64.8 \%$ of their sampled household heads did not attain formal schooling. Idoko and Sabo (2014) noted that farmers' level of education influences adoption of technologies positively, hence the likelihood adopting the improved groundnut seeds is higher among educated farmers than the uneducated respondents. Oyewole and Ojeleye (2015) also noted that education propels farmers to adopt innovations and technologies that are vital for enhancing productivity. Majority of the adopters $(73 \%)$ and non-adopters (53\%) (See Table 1) had farm sizes ranging between 1-3 ha with averages of 2.2 and 1.4 ha respectively. In total, the average farm owned by groundnut farmers in the study area was 1.6 ha. This implies that the farmers are predominantly small scale groundnut producers because according to a report by Federal Office of Statistics, FOS, (1999), cited in Mgbenka and Mbah (2016), farmers whose production capacity falls between 0.1 and 4.99 hectares holding are small holder farmers. Idoko and Sabo (2014) in their study of groundnut farmers in Nigeria reported similar findings. 
Table 1: Socio-Economic Characteristics of the Respondents

\begin{tabular}{|c|c|c|c|}
\hline $\begin{array}{l}\text { Socioeconomic } \\
\text { Variables }\end{array}$ & $\begin{array}{l}\text { Adopters } \\
(\mathrm{N}=33)\end{array}$ & $\begin{array}{l}\text { Non- } \\
\text { adopters } \\
(\mathrm{N}=87)\end{array}$ & $\begin{array}{c}\text { Total } \\
(\mathrm{N}=120)\end{array}$ \\
\hline \multicolumn{4}{|l|}{$\overline{\text { Age }}$} \\
\hline$<21$ & 0.0 & 1.1 & 0.8 \\
\hline $21-30$ & 12.1 & 25.3 & 21.7 \\
\hline $31-40$ & 30.3 & 34.5 & 33.3 \\
\hline $41-50$ & 39.4 & 21.3 & 26.7 \\
\hline$>50$ & 18.2 & 17.8 & 17.5 \\
\hline Mean(years) & 44.0 & 41.0 & 41.8 \\
\hline \multicolumn{4}{|l|}{ Household size } \\
\hline$<5$ & 36.4 & 50.6 & 46.7 \\
\hline $5-10$ & 45.4 & 29.9 & 34.1 \\
\hline$>10$ & 18.2 & 19.5 & 19.2 \\
\hline Mean & 7 & 6 & 6.5 \\
\hline \multicolumn{4}{|l|}{ Education } \\
\hline $\begin{array}{l}\text { No formal } \\
\text { Education }\end{array}$ & 21.2 & 46.0 & 39.2 \\
\hline Adult Education & 17.3 & 5.0 & 9.1 \\
\hline Primary sch. & 33.3 & 25.3 & 26.5 \\
\hline Secondary sch. & 18.2 & 18.4 & 18.3 \\
\hline Post-Secondary & 10.0 & 5.3 & 6.9 \\
\hline \multicolumn{4}{|l|}{ Farm size } \\
\hline$<1.0$ & 18.2 & 40.2 & 34.2 \\
\hline $1.0-3.0$ & 72.7 & 52.9 & 58.3 \\
\hline$>3.0$ & 9.1 & 6.9 & 7.5 \\
\hline Mean(ha) & 2.2 & 1.4 & 1.6 \\
\hline \multicolumn{4}{|l|}{$\begin{array}{l}\text { Extension } \\
\text { contact }\end{array}$} \\
\hline None & 21.2 & 64.4 & 52.5 \\
\hline $1-3$ & 45.5 & 34.5 & 37.5 \\
\hline$>3$ & 33.3 & 1.1 & 10.0 \\
\hline \multicolumn{4}{|l|}{$\begin{array}{l}\text { Farming } \\
\text { Experience }\end{array}$} \\
\hline $1-20$ & 78.8 & 77.0 & 77.5 \\
\hline $20-40$ & 18.2 & 21.9 & 21.7 \\
\hline$>40$ & 3.0 & 1.1 & 0.8 \\
\hline Mean (years) & 17 & 16 & 16.2 \\
\hline $\begin{array}{l}\text { Cooperative } \\
\text { association } \\
\text { Member }\end{array}$ & 33.3 & 8.0 & 24.2 \\
\hline Non-member & 66.7 & 92.0 & 75.8 \\
\hline
\end{tabular}

Still from Table 1, it was observed that both groups of farmers had long farming experience with total average of 16 years. It is expected that with increasing years of farming, farmers gain experience in the art of farming to the advantage of gaining understanding and increasing productivity. This trend portrayed good signal for adoption of groundnut improved technologies in the study area as experienced farmers tend to understand the importance of technologies in farming. A great deal of responsibilities lies with extension workers to bring about change in the productivity and living standard of farmers. In line with this, it is therefore not surprising that more $(64 \%)$ non-adopters had no extension contact in the last year prior to the study as compared to only about $21 \%$ of adopters that did not receive any contact (Table 1). Furthermore, there were more $(45.5 \%)$ of adopters than non-adopters that had 1-3 contacts. Insufficient access to extension services affects the level of technology adoption by farmers which consequently affect production. Adekanye et al. (2009) had reported that extension services have often been ineffective in food and agriculture implying that more is needed in the area of extension services.

In terms of membership of cooperative society, majority of both adopters (66.7\%) and nonadopters $(92.0 \%)$ were not members. This could have negative consequence on adoption as majority if not all of intervention projects and programs are extended to farmers who are in groups. This implies that majority of the farmers cannot enjoy the benefit of working as group.

Impact of Adoption of Improved Groundnut Seed Varieties on the yield of Farmers

Table 2 shows the z-test statistics conducted to analyse the impact of adoption of improved groundnut seeds on the yield of the farmers. The result indicated that expectedly adopters had higher mean yield $(1053.96 \mathrm{~kg} / \mathrm{ha})$ as compared to non-adopters $(909.76 \mathrm{~kg} / \mathrm{ha})$. The yield of adopters falls within the yield usually obtained in Nigeria and Ghana while that of non-adopters is slightly below that obtained as FAOSTAT (2011) 
reported that groundnut yield in Nigeria and Ghana were between $1000 \mathrm{~kg} / \mathrm{ha}$ to $1200 \mathrm{~kg} / \mathrm{ha}$. When the means were compared, a mean yield difference of $144.20 \mathrm{~kg} / \mathrm{ha}$ was calculated. Though this mean difference between the two categories is not much, it gave a Z-value of 3.272 that was significant at $p<0.01$. This indicates that adoption of improved groundnut seeds significantly and positively impacted on the yield of the farmers. Studies within and outside the country have shown similar findings of positive impact of adoption of improve seed on yield of farmers (Mendola, 2007; Becerril and Abdulai, 2009; Awotide et al., 2012).

Table 2: Impact of Adoption of Improved Groundnut Seed

\begin{tabular}{lllll}
\hline Category & Mean (kg/ha) & Standard Dev. & $\begin{array}{l}\text { Mean } \\
\text { Difference(kg/ha) }\end{array}$ & Z-value \\
\hline Adopters & 1053.96 & 233.10 & 144.20 & $3.272^{* * *}$ \\
Non-adopters & 909.76 & 269.91 & & \\
\hline
\end{tabular}

\section{Factors Influencing Adoption of Improved Seeds}

Four variables significantly explained the probability to adopt improved groundnut seed. Out of the four, three (age, educational attainment, farming experience) were household related while one (membership of cooperative association) is an institutional variable (Table 3). The four variables all had positive influence on adoption.

The positive relationship between age and adoption of improved seed indicated that older farmers were more interested to adopt improved groundnut seeds than younger farmers. The result concurs with Shiferaw et al. (2010) and Idoko and Sabo (2014), however, Oyewole and Ojeleye (2015) and Ahmed et al. (2016) in contrast recorded negative relationship between age and adoption. The role of a farmer's age in explaining technology adoption has been controversial. Older people are sometimes thought to be less amenable to change and hence reluctant to change their old ways of doing things. In this case, age is expected to have a negative impact on adoption. On the other hand, older people may have higher accumulated capital, more contacts with extension and preferred by credit institutions predisposing them to technology adoption than younger ones (Muyanga, 2009). This could be the case with the respondents in this study.
The estimated coefficient for education was positive and significant at 1 percent level of probability. This implies that education was positively related to adoption of improved farm practices. The implication of this is that, adoption of improved groundnut seed would increase with attainment of higher levels of education by the farmers. They are more likely to adopt technology as compared to their less educated counterparts who would not want to risk with new technologies until they have seen the benefits. Educated farmers have more exposure to the external environment and accumulated knowledge through formal learning, which enhances their ability to perceive, interpret, and respond to new events in the context of production. Similar results have been found in past works of adoption studies (Shiferaw et al. 2010; Wainaina et al., 2014; Oyewole and Ojeleye, 2015; Ahmed et al., 2016).

Farming experience was significant at $1 \%$ level of probability implying that farmers with more experience in groundnut production are more likely to adopt improved seed varieties than those lacking in these human capital assets. Shiferaw et al. (2010) and Ahmed et al. (2016) recorded similar results. It has been noted that experienced farmers have more knowledge, skills, and positive attitudes to farming that enables them to easily understand and be 
familiar with the benefits of new technology better than less experienced counterpart (Shiferaw et al., 2010; Ahmed et al., 2016).

Membership in an association had a strong positive correlation with adoption of improved seeds $(P<0.001)$. This implies that farmers who belong to associations are more likely to adopt improved seeds. Past studies (Ntege-Nanyenya et al., 1997; Lapar and Pandey, 1999; Mugisha et al., 2004; Shiferaw et al., 2010; Ibrahim et al., 2012) established similar results in their studies. Extension agents and Non-governmental organisations tend to pass agricultural messages through groups and inter-personal linkages during group meetings (Ntege-Nanyenya et al., 1997).

Table 3: Factors Influencing Adoption of Improved Seed

\begin{tabular}{lcccc}
\hline Variables & Coefficients & Std. error & T-Value & $\begin{array}{c}\text { Marginal } \\
\text { effect }\end{array}$ \\
\hline Age & 0.035 & 0.012 & $2.958^{* * \star}$ & 0.053 \\
Household size & -1.069 & 0.928 & -1.153 & -0.161 \\
Education & 0.667 & 0.249 & $2.674^{* * *}$ & 0.100 \\
Farm size & -0.087 & 0.068 & -1.280 & -0.013 \\
Extension contact & -0.124 & 0.235 & -0.527 & -0.019 \\
Farming experience & 1.386 & 0.306 & $4.533^{* * \star}$ & 0.209 \\
Land tenure & 0.028 & 0.035 & 0.817 & 0.004 \\
Cooperative association & 0.718 & 0.264 & $2.720^{* * *}$ & -0.108 \\
Constant & -1.332 & 2.185 & -0.609 & \\
Log likelihood function & -44.980 & & & \\
LR test & 51.200 & & & \\
DF & 8 & & & \\
Cragg-Uhler R-Square & 0.502 & & & \\
\hline
\end{tabular}

\section{CONCLUSION}

From the study it could be concluded that the level of adoption of improved groundnut seed in the study area is low though there was a significant positive impact of adoption on the farmers. Also from the study, age, level of education, farming experience and membership of cooperative association were the factors that positively increase probability of adoption of improved groundnut seeds. It is therefore recommended that the Research Institutes in charge of developing the seeds and ADPs should improve on their effort to promote the technology to farmers for more adoption.

\section{REFERENCES}

Adekanye, T. O., Otitolaiye, J. O. and Opaluwa, H. I. (2009). Food and Agricultural Production in Nigeria: Some Empirical considerations for Engendering Economic Policy for Africa Paper prepared for presentation at IAFF conference on Feminist Economics Boston Massachusetts, USA (26 th $-28^{\text {th }}$ June) pp. 1-20.

Ahmed, M. H., Mesfin, M. H., Abady, S., Mesfin, W. and Kebede, A. (2016). Adoption of improved groundnut seed and its impact on rural households' welfare in Eastern Ethiopia. Cogent Economics and Finance, 4:1-12.

Awotide, B.A., Diagne, A., Wiredu, A.N., and Ebihomon, V.O. (2012). Wealth status and agricultural technology adoption among smallholder rice farmers in Nigeria. OIDA. International Journal of Sustainable Development, 5(2):97-114. 
Awotide, B.A., Karimov, A. A. and Diagne, A. (2016). Agricultural technology adoption, commercialization and smallholder rice farmers' welfare in rural Nigeria. Agricultural and Food Economics, 4(3):34-41.

Becerril, J. and Abdulai, A. (2009). The impact of Improved Maize Varieties on Poverty in Mexico:

A Propensity Score-Approach. World Development, 38:1024-1035.

Besley, T. and Case, A. (1993). Modeling Technology Adoption in Developing Countries. The American Economic Review, 83:396-402.

Coelli, T. and Fleming, E. (2004). Diversification economies and specialization efficiencies in a mixed food and coffee smallholder farming system in Papua New Guinea. Agricultural Economics, 31:229-239.

FAOSTAT (Food and Agriculture Organization of the United Nations) (2011). FAOSTAT Database. http://faostat.fao.org. Accessed May 2012.

Harkness, C. Kolawole, K. B. and Yayock, J. H. (1976). Groundmut Research in Nigeria. Samaru Conference Paper 7, Institute for Agricultural Research, IAR, A.B.U. Zaria, Nigeria.

Ibrahim, M., Florkowski, W. J. and Kolavall, S. (2012). The Determinants of Farmer Adoption of Improved Peanut Varieties and their Impact on Farm Income: Evidence from Northern Ghana. Selected Paper prepared for presentation at the Agricultural and Applied Economics Association Annual Meeting, Seattle, WA, August 12-14, 2012.

Idoko, M. D. and Sabo, E. (2014). Challenges in groundnut production and adoption of groundnut production technology information packages among women farmers. Agriculture and Biology Journal of North America, 5(6):252-258.

Lapar, L. M. and Pandey, S. (1999). Adoption of Soil Conservation: The case of Philippine uplands: Agricultural Economics, 21:241256.
Mendola, M., (2007). "Agricultural Technology Adoption and Poverty Reduction: A propensityScore Analysis for Rural Bangladesh". Food Policy, 32:372-393.

Mgbenka, R. N. and E. N. Mbah (2016). A review of small holder farming in Nigeria: Need for transformation. International Journal of Agricultural Extension and Rural Development Studies, 3(2):43-54.

Mugisha, S. Ogwal-O, R., Ekere, W. and Ekiyar, V. (2004). Adoption of IPM groundnut Technologies in Eastern Uganda. African Crop Science Journal, 12(4):383-391. ISSN 1021-9730/2004

Muyanga, M. (2009). Smallholder adoption and economic impacts of tissue culture banana in Kenya. African Journal of Biotechnology, 8(2):23-31.

NACGRAB (2011). Catalogue of Crop Varieties Released and Registered in Nigeria. Vol. No. 3 Updated as of December 2011. Moor Plantation, Ibadan, Nigeria.

NAERLS (2011). Agricultural Survey for 2011 wet seasons. National Agricultural Extension Research and Liaisons Services. Ahmadu Bello University, Zaria, Nigeria.

National Bureau of Statistics, NBS, (2016). Nigerian Gross Domestic Product Report. Quarter One of 2016, Issue 9. The Federal Republic of Nigeria, Garki, Abuja, Nigeria.

National Bureau of Statistics, NBS, (2018). Labour Force Statistics Employment by Sector Report. Q3 2017 Vol. 2. The Federal Republic of Nigeria, Garki, Abuja, Nigeria.

Ndanitsa, M.A. and Umar, I. S. (2007). Optimum Farm Plan for Fadama Farm in Niger State, Nigeria. Journal of Agricultural Extension, 4(2):46 - 55.

Ndjeunga, J., Ntare, B. R., Abdoulaye, A., Ibro, A., Zarafi, M. A., Cisse, Y., Moutari, A., Kodio, O., Echekwu, C. A., Mohammed, S. G. and Micko, I. (2010). Farmer preferences for groundnut traits and varieties in West Africa: Cases of Mali, Niger and Nigeria, Working Paper Series 
no. 27. Patancheru 502 324, Andhra Pradesh, India: International Crops Research Institute for the Semi-Arid Tropics. 32pp.

Ndjeunga, J., B.R. Ntare, H. Ajeigbe, C.A. Echekwu, A. lbro and A. Amadou (2013). Adoption and Impact of Modern Groundnut Varieties in Nigeria. www.grainlegumes.cgiar.org.

Ntege-Nanyenya, W., Mugisha-Mutetika, M.,Mwangi, W. and Verkuijl, H. (1997). An assessment of the factors affecting adoption of maize production technologies in lganga District, Uganda, Addis Ababa, Ethiopia: National Agricultural Research Organisation (NARO) and International Maizeand Wheat Improvement Centre (CIMMYT). 30pp.

Obuo, J.E.P., Nangoti, N., Nalyongo, P., AkurutAkol, H. and Otutu, J. (2004). Community based groundnut seed production, and dissemination for sustainable smallholder agriculture in Teso farming system. SAARI Final Technical Report TPF 36.

Odoemenem, I.U. and Obinne, C.P.O. (2010). Assessing the factors influencing the utilization of improved cereal crop production technologies by small-scale farmers in Nigeria. Indian Journal of Science and Technology, 3(1):180-183

Oyewole S. O. and Ojeleye O. A (2015). Factors influencing the use of improved farm practices among small-scale farmers in Kano State of Nigeria. Net Journal of Agricultural Science, 3(1):1-4.
Rachier, G.O. (2005). Groundnut production, Research status and future prospects in Western Kenya. Pages 13-21 in Proceedings of groundnut stakeholders meeting held Tuesday, 14 June 2005 at KARI headquarters conference hall.

Salisu, U.C., Akinola, M. O. and Ajeigbe, H. A. (2007). Effect of Improved Crop Livestock System Adoption on the Productivity of Farmers in Kano State. In: Reviving Agriculture for Sustainable National Growth and Democracy. Proceedings of the $41^{\text {st }}$ Conference of the AgriculturalSociety of Nigeria. Held at Institute for Agricultural Research, Samaru, Ahmadu Bello University, Zaria, October 22nd-26th.

Shiferaw, B., Muricho, G., Okello, J., Kebede, T. A. and Okecho, G. (2010). Adoption of Improved Groundnut Varieties in Uganda. Research Report no. 5. Patancheru 502 324, Andhra Pradesh, India: International Crops Research Institute for the Semi-Arid Tropics. $36 \mathrm{pp}$.

Wainaina, P., Songporne, T., and Matin, Q. (2014). Improved seeds, fertilizer or natural resource management? Evidence from Kenya's smallholder maize farmers. Paper prepared for presentation at the EAAE 2014 Congress Ljubljana, Slovenia.

Zekeri, M. and Tijjani, I. (2013). Resource use efficiency of groundnut production in Ringim Local Government Area of Jigawa State, Nigeria. Agro-search, 13(2):42-50. 